\title{
Comparison of traps for capture of alate aphids (Homoptera, Aphidinea) in apricot tree orchards
}

\author{
L Avinent *, A Hermoso de Mendoza, G Llácer \\ Instituto Valenciano de Investigaciones Agrarias (IVIA), Apartado Oficial, 46113 Moncada, Valencia, Spain
}

(Received 25 September 1990; accepted 24 April 1991)

\begin{abstract}
Summary - Three types of trap, yellow water trap (Moericke), green water trap and sticky fishing-line trap (placed at 2 orientations and at 2 heights) were used to sample alate aphid populations in 2 apricot tree orchards infected with sharka (plum pox) virus. These traps were operated in the spring of 1988 and 1989 at 2 locations in Valencia (Spain); 149086 aphids were caught. Aphis gossypii was the most important species in our orchards since it was the most abundant in fishing-line traps. In these traps height had an influence in species composition, while orientation did not. Yellow colour attraction was very clear for Aphis spiraecola while colour attraction was not clear for $A$ gossypii. Very different results were obtained with the 3 types of trap. The percentage of $A$ spiraecola in yellow traps was much higher than that in the green traps and the percentage in green traps was much higher than that in the fishing-line traps. The percentage of $A$ gossypii in fishing-line traps was much higher than that in the green traps and the percentage in green traps was higher than that in the yellow traps.
\end{abstract}

aphid / yellow trap / green trap / fishing-line trap / sharka

Résumé - Comparaison de pièges pour l'échantillonnage des pucerons ailés (Homoptera, Aphidinea) dans deux vergers d'abricotiers. Trois modèles de pièges, piège jaune à eau (Moericke), piège vert à eau et piège à fils englués (2 orientations et 2 hauteurs) ont été essayés pour échantillonner les populations de pucerons ailés dans 2 vergers d'abricotiers infectés par le virus de la sharka (plum pox virus). Ces pièges ont été mis en place aux printemps 1988 et 1989, dans 2 localités de Valencia (Espagne) (tableau 1). 149086 pucerons ont été capturés. L'espèce la plus importante a été Aphis gossypii puisqu'elle a été la plus abondante sur les pièges à fils englués. Sur ces pièges la hauteur a eu une influence sur la composition des espèces, mais non l'orientation (tableaux II, III). L'attraction de la couleur jaune a été très marquée pour Aphis spiraecola (tableau IV) tandis que cette attraction n'a pas été claire pour A gossypii. On a obtenu des résultats très différents selon le piège utilisé (tableau V, fig 2). Le pourcentage de A spiraecola sur le piège jaune a été beaucoup plus élevé que sur le piège vert et le pourcentage sur le piège vert plus élevé que sur le piège à fils. Le pourcentage de A gossypii sur le piège à fils a été beaucoup plus élevé que sur le piège vert et le pourcentage sur le piège vert a été plus élevé que sur le piège jaune.

puceron / piège jaune / piège vert / piège à fils englués / sharka

\footnotetext{
* Correspondence and reprints
} 


\section{INTRODUCTION}

Within the framework of epidemiological studies of sharka (plum pox) virus carried out at the IVIA, the aphid populations present in orchards of stone fruit trees have been determined as a step prior to the study of the possible vectors of the virus.

In an initial experience conducted during 1986 and 1987, aphid populations on apricot, plum and peach plantings were studied in several areas of Spain where the disease had been detected. Yellow water traps (Moericke, 1951) were used in this study (Avinent et al, 1989).

These traps are very selective for Aphis spiraecola (Seif, 1988; Labonne et al, 1989), one of the most abundant species in Spanish citrus and fruit tree orchards (Hermoso de Mendoza et al, 1986; Avinent et al, 1989). That is why the sticky fishing-line traps (Labonne et al, 1983) were used in 1988 and 1989 to study the general aphid population in apricot tree orchards in Valencia, Spain. Fishing-line traps are non-attractant and therefore may be used to study aerial plankton in a particular area if no suction trap is available (Labonne et al, 1989).

Collections of alate aphids intercepted in flight by these traps have been compared with those of alate aphids which landed in coloured (yellow and green) water traps. Green water traps, similar to those used by Irwin (1980), were used because of their likeness to the colour of the foliage.

To our knowledge, yellow and green water traps have already been compared in citrus (Lara et al, 1976; Seif, 1988), in soybean fields (Halbert et al, 1986) and in potato (Boiteau, 1990). Sticky fishing-line traps were compared with yellow water traps and suction traps (Labonne et al, 1989). No work has been done on the comparison of yellow, green and sticky fishing-line traps in fruit tree orchards. Results of this comparison are reported here.

\section{MATERIALS AND METHODS}

The experiments were conducted in the spring of 1988 (25 April-10 June) and 1989 (21 April-16 June) in 2 apricot tree orchards at 2 different locations in the Valencia region, Alfarp and Carlet, where an important natural spread of the sharka virus had been detected (García et al, 1989). Both orchards are in a citrus and stone fruit tree area. The orchard in Alfarp is a 0.5 ha dryland with apricot trees cv Canino planted in 1979.
The orchard in Carlet measures 0.83 ha and is situated on irrigated land with apricot trees cv Corbató planted in 1962. The traps used were as follows.

\section{Fishing-line traps}

Fishing-line traps (Labonne et al, 1983): these consisted of a wooden frame $(31 \times 28 \mathrm{~cm})$ and transparent polyamide threads $(0.4 \mathrm{~mm}$ thick), fixed vertically and $3.5 \mathrm{~mm}$ apart. The actual capture area $(25.5 \times 26.5$ $\mathrm{cm}$ ) was sprayed with a sticky substance by means of a Soveurode aerosol. Two fixed metal stands $(1 \mathrm{~m}$ apart), placed in NE/SW (orientation 1) and NW/SE (orientation 2) orientations (perpendicular and parallel to the position of tree lines), were used to suspend these traps, leaving the sticky surfaces $\approx 60 \mathrm{~cm}$ and $160 \mathrm{~cm}$ above ground level; for trap codes see table $\mathrm{I}$.

\section{Yellow water traps}

Yellow water traps (Moericke, 1951) were in the form of round pans, $30 \mathrm{~cm}$ in diameter and $10 \mathrm{~cm}$ deep. The insides were painted yellow and were filled with water; these containers were placed on a metal stand $1.5 \mathrm{~m}$ high. The yellow colour used was Titanlux synthetic enamel 529; colour reflective spectrogram (fig 1) was determined at 10-nm intervals between 400-700 $\mathrm{nm}$ with a Labscan II spectrocolorimeter. For trap codes see table I.

\section{Green traps}

Green traps had the same characteristics as the traps mentioned above, apart from the pan which was painted green. The green colour used was Titanlux synthetic enamel 516; colour reflective spectrogram (fig 1) was determined at 10-nm intervals between 400-700 $\mathrm{nm}$ with a Labscan II spectrocolorimeter. For trap codes see table I.

The aphids caught with these 3 types of trap were collected twice a week and maintained in alcohol until

Table I. Codes for traps and locations.

\begin{tabular}{|c|c|c|c|c|}
\hline \multirow[t]{3}{*}{ Yellow green } & \multicolumn{4}{|c|}{ Fishing-line } \\
\hline & \multicolumn{2}{|c|}{$N E / S W$} & \multicolumn{2}{|c|}{ NW/SE } \\
\hline & $60 \mathrm{~cm}$ & $160 \mathrm{~cm}$ & $60 \mathrm{~cm}$ & $160 \mathrm{~cm}$ \\
\hline ALFARP AY* AG & A1D & A1U & A2D & $\mathrm{A} 2 \mathrm{U}$ \\
\hline CARLET CY CG & C1D & C1U & $\mathrm{C} 2 \mathrm{D}$ & $\mathrm{C} 2 \mathrm{U}$ \\
\hline
\end{tabular}

* Numbers 8 and 9 added to these codes indicate year collection $(1988,1989)$. 


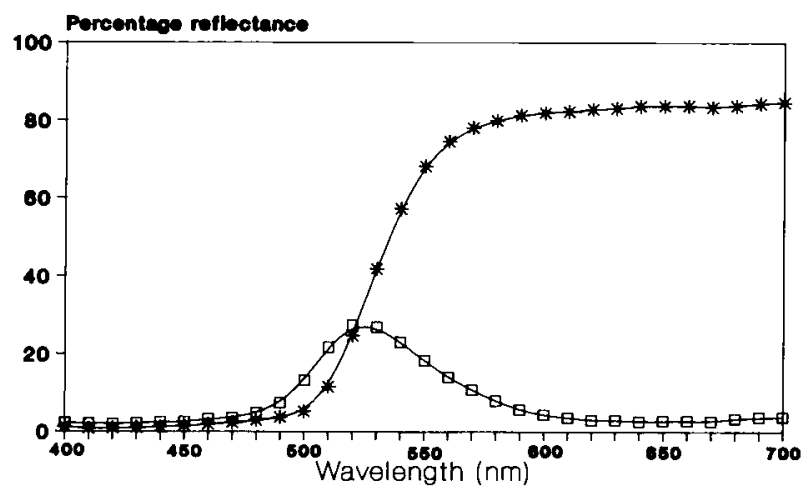

Fig 1. Spectrogram for coloured traps. $*$ yellow trap; $\square$ green trap.

identification according to the procedure of Ilharco (1965).

For statistical determination of total real values an analysis of variance was made, and Duncan's multiple range test $(95 \%)$ was used to compare means. We focused on the colour preference for water traps, and height and orientation for fishing-line traps. Therefore we considered these effects to be fixed. On the other hand, year and location were introduced into the model in order to widen the inference space; these effects were then considered to be random.

To compare the distribution of the species on the traps (percentages) a factorial analysis of correspondences was made, considering all the factors studied: colour (for water traps), height and orientation (for fishing-line traps), location and year (for water and fishingline traps).

\section{RESULTS}

A total of 149086 aphids was collected over the 2-yr study. The most abundant species or groups of species were: Aphis gossypii Glover, 1877; Aphis spiraecola Patch, 1914; Hyalopterus pruni (Geoffroy, 1762); Myzus persicae (Sulzer, 1776); Pemphigidae spp; and Toxoptera aurantii (Boyer de Fonscolombe, 1841).

The set of "others" (tables II to V) was extremely diverse, including several species but with few individuals within each species (compared to the values reached by the species mentioned above).

\section{Fishing-line traps}

\section{Effect of height and orientation}

Table II shows the mean number of aphids collected with sticky fishing-line traps at 2 heights
$(60 \mathrm{~cm}$ and $160 \mathrm{~cm})$. Means were obtained from trap values in both locations, years and orientations.

Table III shows the mean number of aphids collected, with these traps in both orientations. Means were obtained from trap values in both locations, years and heights.

Significant differences were only found for $A$ gossypii. These results are independent of location and year: in both locations and years $A$ gossypii was more abundant at $60 \mathrm{~cm}$ for heights, and at NW/SE for orientations.

\section{Water traps}

\section{Effect of colour}

Table II shows the mean number of aphids collected with yellow and green water traps. Means

Table II. Mean number of aphids collected in fishingline traps at 2 heights.

\begin{tabular}{lrr}
\hline Species & $160 \mathrm{~cm}$ & \multicolumn{1}{l}{$60 \mathrm{~cm}$} \\
\hline & & \\
A gossypii & $1710.2 \mathrm{~b}^{*}$ & $66848.4 \mathrm{a}$ \\
A spiraecola & $638.1 \mathrm{a}$ & $519.6 \mathrm{a}$ \\
H pruni & $89.2 \mathrm{a}$ & $328.4 \mathrm{a}$ \\
M persicae & $18.2 \mathrm{a}$ & $19.6 \mathrm{a}$ \\
Pemphigidae & $109.5 \mathrm{a}$ & $89.7 \mathrm{a}$ \\
Taurantii & $15.9 \mathrm{a}$ & $10.5 \mathrm{a}$ \\
Others & $152.7 \mathrm{a}$ & $272.5 \mathrm{a}$ \\
& & \\
Total No & 20012 & 62389 \\
\hline
\end{tabular}

\footnotetext{
* Means within a species followed by the same letter are not different at the $P=0.05$ level using Duncan's multiple range test.
} 
Table III. Mean number of aphids collected with fishing-line traps at 2 orientations.

\begin{tabular}{lrr}
\hline Species & NE/SW & \multicolumn{1}{c}{ NW/SE } \\
\hline A gossypii & $3192.6 \mathrm{~b}^{*}$ & $5166.0 \mathrm{a}$ \\
A spiraecola & $459.1 \mathrm{a}$ & $698.6 \mathrm{a}$ \\
H pruni & $189.7 \mathrm{a}$ & $227.9 \mathrm{a}$ \\
M persicae & $11.1 \mathrm{a}$ & $26.7 \mathrm{a}$ \\
Pemphigidae & $85.9 \mathrm{a}$ & $113.4 \mathrm{a}$ \\
Taurantii & $10.5 \mathrm{a}$ & $15.9 \mathrm{a}$ \\
Others & $151.6 \mathrm{a}$ & $273.6 \mathrm{a}$ \\
& & \\
Total No & 32084 & 50317 \\
\hline
\end{tabular}

* Means within a species followed by the same letter are not different at the $P=0.05$ level using Duncan's multiple range test.

were obtained from trap values in both locations and years.

Significant differences were only found for $A$ gossypii and $A$ spiraecola. More $A$ spiraecola specimens were caught in the yellow traps than in the green traps, in both locations and years. Conversely, A gossypii seemed to show a preference for the green traps rather than for the yellow traps because more $A$ gossypii specimens were caught in green than in yellow traps. These results are independent of location. Year had an influence in the collection of $A$ gossypii: in 1989 no significant differences were found between yellow and green traps.

Table IV. Mean number of aphids collected in coloured water traps.

\begin{tabular}{lrr}
\hline Species & Yellow & \multicolumn{1}{l}{ Green } \\
& & \\
\hline A gossypii & $1137.5 \mathrm{~b}^{\star}$ & $2207.0 \mathrm{a}$ \\
A spiraecola & $9815.5 \mathrm{a}$ & $2836.7 \mathrm{~b}$ \\
H pruni & $5.7 \mathrm{a}$ & $14.2 \mathrm{a}$ \\
M persicae & $51.7 \mathrm{a}$ & $42.2 \mathrm{a}$ \\
Pemphigidae & $8.5 \mathrm{a}$ & $10.2 \mathrm{a}$ \\
Taurantii & $127.2 \mathrm{a}$ & $162.2 \mathrm{a}$ \\
Others & $152.5 \mathrm{a}$ & $99.7 \mathrm{a}$ \\
& & 21490 \\
Total No & 45195 & \\
\hline
\end{tabular}

* Means within a species followed by the same letter are not different at the $P=0.05$ level using Duncan's multiple range test.

\section{Comparison of distribution of species in the traps (percentages)}

Table $V$ shows the cumulative percentages between species of aphids collected with the different types of traps. Species composition was different for each type of trap. In yellow traps there was a dominant species: $A$ spiraecola. Green traps mainly collected 2 species: $A$ spiraecola and $A$ gossypii. Fishing-line traps had one dominant species: A gossypii. The factorial analysis of correspondences (fig 2), performed to analyze all these percentages showed that the 3 types of traps collected aphids in a different way. The 2 axes represented provided $83.55 \%$ of information relevant to the variables analysed.

\section{DISCUSSION}

Sticky fishing-line traps have been little studied thus far as a sampling method for alate aphids. Labonne et al (1989) showed that these traps could be used as a substitute for the suction traps to study aphid populations flying close to the vegetative canopy. If we assume this point to be valid, results from the study for fishing-line traps (tables II and III), show that the species composition in the orchards studied is far different from the known data in other countries where sharka spreads. A gossypii is the most abundant species in our orchards. Labonne et al (1989) found, on the contrary, that in the south-east of France there was no dominant species, but sev-

Table V. Percentages between species for the different types of traps and total number of aphids caught.

\begin{tabular}{lrrr}
\hline Species & Yellow & Green & Fishing-line \\
\hline & & & \\
\hline A gossypii & 10.07 & 41.08 & 81.15 \\
A spiraecola & 86.87 & 52.80 & 8.11 \\
H pruni & 0.05 & 0.26 & 4.05 \\
$M$ persicae & 0.46 & 0.79 & 0.37 \\
Pemphigidae & 0.07 & 0.19 & 1.93 \\
Taurantii & 1.13 & 3.02 & 0.26 \\
Others & 1.35 & 1.86 & 4.13 \\
& & & \\
Total No & 45195 & 21490 & 82401 \\
\hline
\end{tabular}




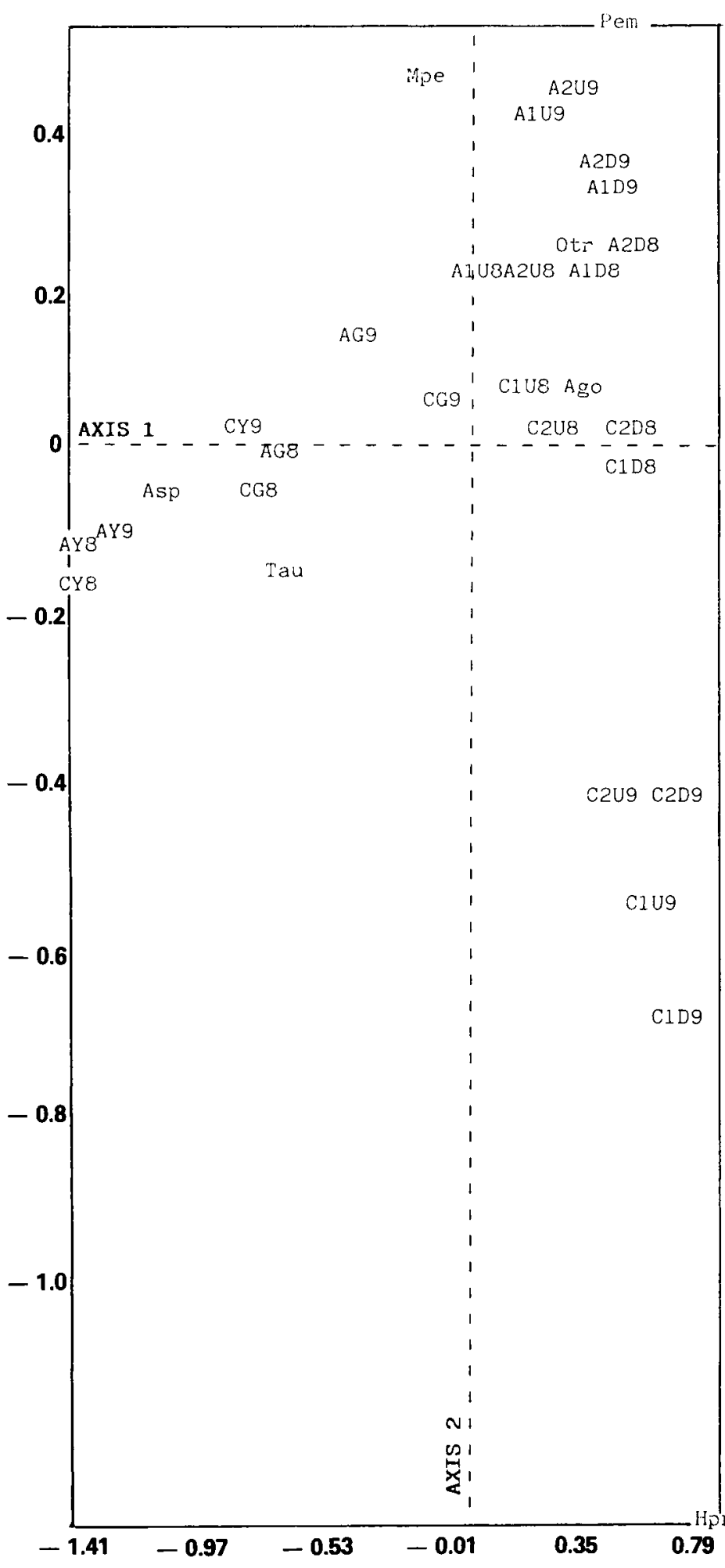

Fig 2. Factorial analysis of correspondences (percentages). Simultaneous representation of species and traps. Plane of axes 1 and $2(69.95 \%$ and $13.60 \%$ respectively of the total inertia of the system). Axis $3(10.00 \%)$ has not been drawn. Ago: A gossypii; Asp: A spiraecola; Hpr : $H$ pruni; Mpe : Mpersicae; Pem : Pemphigidae; Tau : $T$ aurantii; Otr : Others. For trap codes see table l. eral with nearly the same number of specimens collected. Presumably, the presence of citrus in the vicinity of our apricot tree orchards had an important influence on aphid populations in fruit tree orchards. In recent years the percentage of $A$ gossypii has increased significantly in citrus orchards in Valencia, while the percentage of $A$ spiraecola has decreased (Hermoso de Mendoza and Moreno, 1989).

A gossypii has never been demonstrated to be a sharka vector. The next important objective is to find out whether this species is a vector of sharka or not. Studies in this regard are ongoing.

As mentioned in the Results section, height and orientation of fishing-line traps were significant only for $A$ gossypii. Differences in heights were far more important than in orientations: rate between number of $A$ gossypii collected at $60 \mathrm{~cm}$ and $160 \mathrm{~cm}$ was 3.9 , while orientation rate was 1.6. In addition, while species composition (percentages) varied when comparing the 2 heights studied, species composition in both orientations was very similar (these data, which have not been shown, can be extrapolated from tables II and III). Labonne et al (1989) also found that height was more important than orientation.

In our experiment we collected the aphids twice a week. However, under our climatic conditions, it would be more advisable to collect the aphids from the fishing-line traps 3 times a week in order to maintain them in proper condition for identification. This consideration contrasts with the experiments reported by Labonne et al (1983). Because of their different climatic conditions, they were able to carry out aphid collections once or twice a week, and the aphids still remained in good condition for identification.

Colour attraction was very clear in $A$ spiraecola (table IV): yellow traps collected more specimens than green traps, in both locations and years, which agrees with the data of Seif (1988). Halbert et al (1986) found no significant preference differences for this species between green and yellow traps, although more $A$ spiraecola were caught in yellow traps. Conversely, colour preference was not clear for $A$ gossypii: in 1988 green traps collected more specimens than yellow traps, and differences were significant; in 1989 preference differences were not significant. In this regard, Roach and Agee (1972) reported that yellow appeared to be a more attractant col- 
our than green for $A$ gossypii, whereas Halbert et al (1986) on the contrary, reported a more marked preference for green than for yellow. Further studies are necessary to clarify this point.

A comparison between percentages of aphid species collected with water traps and fishingline traps was necessary to determine similarities or differences between these traps. Results (table V; fig 2) show that the percentage of $A$ spiraecola in yellow traps was much higher than that in the green traps, and that the percentage in green traps was much higher than that in the fishing-line traps. On the other hand, the percentage of $A$ gossypii in fishing-line traps was much higher than that in the green traps; and in the green traps the percentage was higher than in the yellow traps.

These results show that proportions of the 2 main species are very different depending on the trap used. The question now is to determine which is the best sampling method to study fluctuations of aphid potential vectors of sharka virus. Since for non-persistent virus the attack flight of aphids is sufficient for transmission, we are firstly interested in finding out which aphids actually alight on leaves and shoots of apricot trees and, secondly, whether collection with any of the traps studied gives an accurate indication of aphid populations landing on apricot trees. Studies now in progress should provide an answer to these questions in the near future.

\section{ACKNOWLEDGMENTS}

This work has been supported by the Instituto Nacional de Investigaciones Agrarias (INIA) of Spain (project 8133). L Avinent is the holder of a pre-doctoral fellowship from the Conselleria de Cultura, Educación y Ciencia, Generalitat Valenciana. The authors express their appreciation to S García (EUITA, Valencia) for his help in locating the experimental orchards; $E$ Carbonell (IVIA, Valencia) for his statistical analyses, $C$ Calvo (IATA, Valencia) for assisting with colour spectrogram, and A Borrás (IVIA, Valencia) for assisting with the English translation.

\section{REFERENCES}

Avinent L, Hermoso de Mendoza A, Llacer G (1989) Especies dominantes y curvas de vuelo de pulgones (Homoptera, Aphidinea) en campos de frutales de hueso españoles. Inv Agrar: Prod Prot Veg 4(2), 283-298

Boiteau G (1990) Effect of trap color and size on relative efficiency of water-pan traps for sampling alate aphids (Homoptera: Aphididae) on potato. $J$ Econ Entomo/ 83(3), 937-942

García S, Martín MM, Avinent L, Llácer G, Hermoso de Mendoza A, Serra J (1989) Spread of sharka in apricot trees. 9th Int Symp on Apricot Culture, $\mathrm{Ca}$ serta (Italy). Acta Hortic (in press)

Halbert SE, Zhang GX, Pu ZQ (1986) Comparison of sampling methods for alate aphids and observations on epidemiology of soybean mosaic virus in Nanjin, China. Ann App/ Biol 109, 473-483

Hermoso de Mendoza A, Fuertes C, Serra J (1986) Proporciones relativas y gráficas de vuelo de pulgones (Homoptera, Aphidinea) en los cítricos españoles. Inv Agrar: Prod Prot Veg 1(3), 393-408

Hermoso de Mendoza A, Moreno P (1989) Cambios cuantitativos en la fauna afídica de los cítricos valencianos. Bol San Veg Plagas 15, 139-142

Ilharco FA (1965) Afideos das fruteiras de Portugal continental. Agron Lusit 27(1), 5-86

Irwin ME (1980) Sampling aphids in soybean fields. In: Sampling Methods in Soybean Entomology (Kogan $H$, Herzog DC, eds) Springer-Verlag, NY, 239-259

Labonne G, Fauvel G, Quiot JB (1983) Intérêt des pièges à fils dans l'étude des populations de pucerons ailés. Agronomie 3, 315-326

Labonne G, Lauriaut F, Quiot J (1989) Comparaison de trois types de pièges pour l'échantillonnage des populations de pucerons ailés. Agronomie 9, 547557

Lara IM, Bortoli SA de, Oliveira EA (1976) Atratividade de cores a alguns insetos associados ao Citrus sp. Anais Soc Entomol Brasil 5(2), 157-163

Moericke V (1951) Eine Farballe zur Kontrolle des Fluges von Blattlausen insbesondere der pfirschblattlaus, Myzodes persicae (Sulz). Nachrichtenbl Deutsch Pflanzenschutzd 3, 23-24

Roach SH, Agee HR (1972) Trap colours: preference of alate aphids. Environ Entomol 1(6), 797-798

Seif AA (1988) Comparison of green and yellow water traps for sampling citrus aphids at the Kenya coast. E Afr Agric For J 53(3), 159-161 